\title{
Academic Library Standards and Performance Measures
}

\section{Antoinette M. Kania}

This paper develops a model set of regional accreditation library standards that encompasses qualitative standards for accreditation purposes and suggested quantitative performance measures for local self-evaluation purposes. A core of standards was identified through a content analysis of the existing library standards of the seven higher-education regional accreditation commissions. They were then matched with performance measures identified through the literature, and expert advice from the field was sought twice to comment on (1) the appropriateness of the standards for accreditation purposes by college sector and (2) the usefulness of the performance measures for assessing the achievement of some of the standards. A new set of academic library standards was thus developed with which specific performance measures could be used.

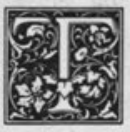

hrough requirements for selfassessment, either as part of a routine in-house evaluation process or as part of an institutional self-study for regional accreditation, college and university librarians find themselves in need of useful and specific methods to help them determine how well their libraries meet the educational and information needs of their clients.

A study was conducted, with the help of a large team of knowledgeable professionals across the country, to enhance selfassessment processes by creating a model set of qualitative, performance-oriented academic library standards from the existing, but quite varied, academic library standards of the seven regional accreditation higher-education commissions. One very specific goal was to make the standards more "outcomes" or performance oriented as well as to differentiate between what ought to be mandatory (must), professionally obligatory (should), or simply advisable (may) for accreditation purposes.

Also, in order to assist libraries in deter- mining the degree to which they achieve the standards in a quantitative sense, appropriate performance measures were identified from the literature and compiled in an annotated bibliography for use in conjunction with the model standards. Using these tools, an academic library could then establish its own local criterion level for the achievement of a given standard and select one of the evaluation methods suggested in order to determine if it has or has not met the expected performance. If the library were to fall short of its expected level of achievement, it could then make changes in procedures, priorities, resources, or whatever is judged to be required, based on the results of its own study.

That there was a need for more useful standards to guide academic library selfstudy was made apparent at an Association of College and Research Libraries (ACRL) preconference institute at the 1980 American Library Association (ALA) Annual Conference in New York. Cosponsored with the Council on Postsecondary Education (COPA), the institute 


\section{"... existing library standards ... were too broad and vague and, gener- ally, just not very useful in guiding self-study."}

brought together by invitation academic librarians with experience as regional accreditation evaluation team members and accreditation association staff members. The participants were asked to explore whether the existing, generally qualitative standards of both the professional association and the institutional accreditation associations could be improved to reflect the practitioners' expressed need for more quantitative guidance in the evaluation of their libraries by placing more emphasis on outcomes through the possible use of performance measures.

The questions raised at the initial ACRL/COPA institute prompted this author later to conduct a literature review to determine the status of academic library evaluation in the accreditation process. Studies on the topic had indeed been conducted, first by Morris Gelfand, then later others by Dudley Yates, Johnnie Givens and Wanda Sivells, Ronald Leach and George Grant. ${ }^{1}$ All clearly illustrated that librarians involved with regional accreditation were dissatisfied with the existing library standards. They were too broad and vague and, generally, just not very useful in guiding self-study.

At the same time, considerable research was being conducted to yield a substantial collection of performance measures for use in the evaluation of academic libraries. Such performance measures were identified in major areas relevant to this studyevaluation of library use and the user, document availability, evaluation of the collection, and the evaluation of reference. . $^{2,4,5}$

Despite the documented existence of performance measures, Rosemary and Paul DuMont maintained that little of the work has been synthesized or widely used in the profession. ${ }^{6}$ They claimed, further, that although there is a need for more re- search to test and refine the existing techniques and/or to develop better ones, there are enough methods available to be of use to librarians in assessing the effectiveness of their libraries.

Other than in the libraries where these measures of use were developed, tested, and, in some cases, replicated, their use for evaluation or self-study purposes goes generally unreported in the literature. Therefore, the actual extent to which they may, in fact, be in use is generally unknown, except as indicated in studies conducted by John Knightly and Mary Casserly, where both present evidence and collected opinion that they are seldom utilized. $^{7}$

Furthermore, in 1985, the committee charged with the revision of the 1975 College Library Standards, after much investigation and discussion, chose not to include performance measures in the new revision. Despite input from college library directors who expressed the specific need for performance measures in the standards, the committee was still reluctant to include them. The College Library Standards Committee simply concluded that "at this point [this was] beyond the scope of its charge."

It therefore became the specific intention of this study to bridge the gap between the dissatisfaction with the library standards of both the regional accreditation agencies and the professional library association and the availability of generally unused performance measures for academic library evaluation.

\section{THE METHOD}

The project was conducted in two parts, the first of which was a content analysis of the existing academic library standards of the seven regional accreditation highereducation commissions in 1984 . The second part was the development and use of three survey instruments to collect expert opinion from librarians, accreditation officials, and performance measures experts to create a newly formulated, more useful set of regional accreditation standards and of linking these standards to appropriate performance measures.

In performing the content analysis-a 
methodology used to analyze documents for recurring thematic characteristics that are then quantified and summarized-ten major subject areas, or topics, were identified from the seven commissions' standards (collection, access, facilities, staff, networking, use, learning resources center concept, budget, faculty participation, and goals and objectives) which incorporated within them fifty-seven subtopics. In the process of reviewing and reorganizing the fifty-seven subtopics to become a cohesive draft of representative standards, the frequency with which the subtopics were cited by the different commissions was considered, and similar subtopics and topics were grouped.

The first survey instrument was developed to solicit expert opinion on the newly created composite set of forty-five standards statements derived from the content analysis. In the instrument, the verb was removed from each statement and respondents were asked to select the most appropriate verb: must to connote that which is mandatory, should to connote that which implies professional obligation, and may to connote that which is advisable. The participants' selection of a particular verb was to indicate what they felt ought to be the appropriate level of adherence to that standard for regional accreditation for their own type of institution (two-year college, four-year college, or university).

The sample to receive this instrument was a purposefully selected group of sixty-five academic library directors with evaluation team experience and regional accreditation commission staff members. Using a purposefully selected sample did, of course, introduce a self-selection bias to the study. However, it was felt that getting an informed and knowledgeable opinion from the respondents on the standards was essential to the success and ultimate usefulness of the final product, so only individuals who had already demonstrated an interest in and experience with academic library standards and regional accreditation were solicited. Eleven of the sample were commission staff memberstwo from each commission except for those with only one staff member. About one-half of the library directors in the sam- ple had participated in the 1980 ACRL/COPA preconference institute and the other half were recommended by their respective accreditation commissions. An attempt was also made to balance the sample by region (Middle states, North Central, North West, etc.) and by sector (twoyear college, four-year college, university, and commission).

The first instrument with the initial draft of forty-five standards had an $85 \%$ response rate. The respondents' ratings of the forty-five derived standards in the instrument were gathered and the relative frequency with which the respondents felt that one of the verbs, must, should, or may was appropriate for each potential standard statement was computed. In all instances, the verb selected most frequently (by $50 \%$ or more of the respondents) became the verb for that standard in the second draft.

The second survey instrument was derived from an analysis of the responses to the first from which nine primary standards using the verb must and twentythree secondary standards using the verbs should and may emerged. The second instrument was sent to the fifty-two individuals who had responded to the first, and they were asked to evaluate the newly drafted standards as being either generally acceptable or generally unacceptable for use in academic library self-study and evaluation for regional accreditation.

The third instrument was in effect a request for expert advice on the applicability and practicality of selected library performance measures that had been tentatively linked to the newly developed individual standards. Some sixty methods of evaluating libraries against the standards had been identified from the literature. Sixteen experts in the field, selected because they had either developed performance measures themselves or had utilized some of the methods in their own libraries and published the results, were asked to comment critically.

\section{THE RESULTS}

Of the ten major topics identified in the content analysis of the existing accreditation standards only five or $50 \%$ were present in all seven commissions' stan- 
". . . the broad focus for library evaluation throughout the accreditation regions was on inputs and processes, not output dimensions."

dards (collections, facilities, staff, access, and networking). When the topic with the next highest level of agreement among the commissions' standards (71\%), "use," was added, a total high of only $60 \%$ agreement could be achieved on what the major areas for consideration ought to be in academic library evaluation for regional accreditation, thereby indicating considerable room for variation across the regions. The broadest coverage of any one commission within the fifty-seven subtopics identified in the content analysis was only $49 \%$.

When Rosemary DuMont's systems model definitions (inputs, processes, outputs) were applied to those five major topics on which all the commissions had agreed, none were output oriented. ${ }^{9}$ It was clear that "collection," "facilities," and "staff" were inputs and "access" and "networking" were processes. Therefore, it seemed that the broad focus for library evaluation throughout the accreditation regions was on inputs and processes, not output dimensions. In fact, five commissions together made only a total of ten references to the next most cited outputoriented topic, "use." Further, two sets of regional accreditation standards made no reference to "use" at all as a component of evaluation for academic libraries. Only $9 \%$ of the subtopics exhibited any outcome orientation, further substantiating this finding.

A deliberate attempt was made to be cognizant of the balance between the systems model components in the formulation of the first draft of the standards from the content analysis. As a result, $18 \%$ of this original composite draft were able to be compiled with an output orientation.

A frequency analysis was conducted on the responses to the first instrument for each of the respondent's institutional sectors and for all respondents. There were two primary purposes to the analysis: (1) to determine if there was a significant enough discrepancy in responses among the various academic library sectors to suggest a need for a separate set, or partial set, of standards for each type; and (2) to be able to organize the standards in priority order according to the levels of adherence to the standards required for institutional accreditation as expressed by the respondents. There was very high agreement $(96 \%)$ among the sectors on the verbs (must, should, may) where at least three of the four sectors agreed. This high level of agreement persisted as well when all possible combinations of sector pairs were compared. It appeared that separate accreditation standards for each of the college sectors were not warranted. It was suggested by the respondents, however, that for those standards where differences between the sectors may be implied, a simple reference to the library's adherence to that standard in order to support its institution's goals (i.e., research) would suffice.

The response rate was $94 \%$ to the second instrument, which asked respondents to react to the general acceptability or non-acceptability of the standards as revised from the first instrument. The overall acceptance to the reformulated standards was over $90 \%$. Only seven of the thirty-two primary and secondary standards had less than $90 \%$ of the respondents rating them as acceptable. None had less than $75 \%$. Therefore, it was decided that the draft of the standards contained within the second instrument would remain intact as the final set of regional accreditation standards to be proposed in this project (see appendix A). The actual number of outcomes standards, according to DuMont's systems model components, did not increase from the first draft to the second, although the relative percentage increased from $18 \%$ to $25 \%$. Because standards were combined, reworded, and added as a result of the redrafting process, four or the eight output-related standards remained virtually the same as in the first draft.

The third instrument, designed to request advice of performance measures experts in the field about the applicability 
and practicality of employing the proposed measures, received a very high rate of return $(94 \%)$, but the data collected were not as rich as one would have expected. While fifteen of the sixteen were returned, only four $(27 \%)$ were, in fact, completed. Fifty percent were at least partially completed.

The responses, while not great in number, did provide useful information on the applicability and practicality of some of the performance measures. Twenty-four $(38 \%)$ of the sixty-four performance measures were identified by the experts as applicable to the standards with which they were linked as well as being considered reasonably practical to replicate in a real library setting. Another fourteen measures (22\%) were also identified as applicable to a given standard, but except in one instance, supporting evidence about the practicality of the application was not included.

It appeared that the individual expert respondents did not know enough about the details of some, or most, of the methods to comment on the practicality as well as their applicability. Those who made the most complete reference to a given measure generally did so with respect only to those particular items and/or areas in which they themselves had published or conducted research.

While the twenty-four measures identified as being both applicable and practical were linked to only ten (31\%) of the thirtytwo standards in the new model set, they, nonetheless, represented major areas of importance in the evaluation of academic libraries in this author's study, i.e., relevance and size of the collection, document availability, reference services, use, and the user. Therefore, on balance, this step, which sought expert advice on performance measures to use with the new proposed regional accreditation standards, can be viewed as reasonably successful given the apparent compartmentalized or measure-specific knowledge about these methods on the part of the experts participating in the study.

\section{SUMMARY}

It appears that academic libraries are currently being examined through a wide variety of requirements for regional accreditation. The standards against which they are evaluated were found to differ across the regions by as much as $50 \%$, not only in length and style, but also in content. They were also found to be primarily input and process oriented. Little emphasis is given to the outcomes dimension despite the regional associations' emphasis on goal-oriented self-study and evaluation for accreditation.

Through this study, it was possible to develop a composite set of regional accreditation library standards that could accommodate the three major academic library sectors with increased overall content coverage more representative of practitioners' concerns and with greatly increased focus on outcomes. Library performance measures were identified and verified as applicable to the proposed accreditation standards as well as practical to use in a real library setting.

Using these tools an academic library can then establish its own local criterion level for the achievement of a given standard and select one of the evaluation methods suggested in order to determine if it has or has not met the criterion level, i.e., achieved the standard at its own level of expected performance. If the library were to fall short of its expected level of achievement, it could then make appropriate changes in policies, procedures, resource allocation or whatever is judged to be required, based on the results of its own study.

\section{REFERENCES}

1. Morris A. Gelfand, "Techniques of Library Evaluation in the Middle States Association," College and Research Libraries 19:305-20 (July 1958); Dudley V. Yates, "An Analysis of Bases Used by Library Evaluators in the Accrediting Process of the Southern Association of Colleges and Schools 
(Ph.D. diss., Florida State Univ., 1973); Johnnie E. Givens and Wanda K. Sivells, "Accreditation Agencies and Library Cooperation in Education," Library Trends 24:361-78 (Oct. 1975); Ronald G. Leach, "Identification and Modification of Criteria and Procedures for Evaluating College and University Libraries by North Central Association Accreditation Teams" (Ph.D. diss., Michigan State Univ., 1980); George C. Grant, "Attitudes of Higher Education Administrators Toward Adequacy of Middle States Association Library Evaluation Criteria and Processes" (Ph.D. diss., Univ. of Pittsburgh, 1982).

2. John Budd and Mike DiCarlo, "Measures of User Evaluation at Two Academic Libraries," Library Research 4:71-84 (Spring 1982); Meredith Butler and Bonnie Gratch, "Planning a User Study-The Process Defined," College and Research Libraries 43:320-30 (July 1982); Harold J. Ettelt, "Book Use at a Small (Very) Community College," Library Journal 103:2314-15 (Nov. 15, 1978); Herman H. Fussler and Julian L. Simon, Patterns in the Use of Books in Large University Libraries (Chicago: Univ. of Chicago Pr., 1969); Anthony Hindle and Michael K. Buckland, "In-Library Book Usage in Relation to Circulation," Collection Management 2:265-77 (Winter 1978); A. K. Jain, "Sampling InLibrary Book Use," Journal of the American Society for Information Science 23:150-55 (May 1972); Allen Kent and others, Use of Library Materials: The University of Pittsburgh Study (New York: Marcel Dekker, 1979); Gene K. Rinkel and Patricia McCandless, "Application of Methodology Analyzing User Frustration," 43:29-36 (Jan. 1983); William Shaw, Jr., "A Practical Journal Usage Technique," College and Research Libraries 39:479-84 (Nov. 1978); Mary K. Trochim, Measuring the Book Use of a Small Academic Library Collection: A Manual (Washington, D.C.: ARL 1985); Richard W. Trueswell, "User Circulation Satisfaction vs. Size of Holdings at Three Academic Libraries," College and Research Libraries 30:204-13 (May 1969); Jo Bell Whitlatch, "Library Use Patterns among Full- and Part-Time Faculty and Students," College and Research Libraries 43:141-53 (Mar. 1983).

3. Michael K. Buckland, Book Availability and the Library User (New York: Pergamon, 1975); Ernest R. DeProspo, Ellen E. Altman and Kenneth E. Beasley, Performance Measures for Public Libraries (Chicago: American Library Assn., 1973); Paul B. Kantor, Objective Performance Measures for Academic and Research Libraries (Washington, D.C.: ARL, 1984); Richard H. Orr and others, "Development of Methodologic Tools for Planning and Managing Library Services," Bulletin of the Medical Library Association 56:235-67 (July 1968); James L. Schofield, A. Cooper and D. H. Waters, "Evaluation of an Academic Library's Stock Effectiveness," Journal of Librarianship 7:207-27 (July 1975); John A. Urquhart and James L. Schofield, "Measuring Readers' Failure at the Shelf in Three University Libraries," Journal of Documentation 28:233-41 (Sept. 1972); Jo Bell Whitlatch and K. Kieffer, "Service at San Jose State University: Survey of Document Availability," Journal of Academic Librarianship 4:169-99 (Sept. 1978).

4. Verner W. Clapp and Robert T. Jordan, "Quantitative Criteria for Adequacy in Academic Library Collections," College and Research Libraries 26:371-80 (Sept. 1965); Cynthia Comer, "List-Checking as a Method for Evaluating Library Collections," Collection Building 3:26-34 (1981); F. Wilfred Lancaster, "Evaluating Collections by Their Use," Collection Management 4:15-43 (Spring/Summer 1982); Manuel Lopez, "The Lopez or Citation Technique of In-Depth Collection Evaluation Explicated," College and Research Libraries 43:251-55 (May 1983); William E. McGrath, "Pragmatic Book Allocation Formula for Academic and Public Libraries with a Test for its Effectiveness," 19:356-69 (Fall 1975); William M. Shaw, Jr., "A Journal Resource Sharing Strategy," Library Research 1:19-29 (Spring/Summer 1979).

5. Richard W. Blood, "Evaluation of On-Line Searches," RQ 22:266-77 (Spring 1983); Thomas Childers, "Managing the Quality of Reference/Information Service," Library Quarterly 42:212-17 (Apr. 1972); Thomas Childers, "The Test of Reference," Library Journal 105:924-28 (Apr. 1980); Edward C. Jestes and W. David Laird, "A Time Study of General Reference Work in a University Library," Research in Librarianship 2:9-16 (Jan. 1968); Victoria Kok and Anton R. Pierce, "The Reference Desk Survey: A Management Tool in an Academic Research Library," RQ 22:181-85 (Winter 1982); Marcia J. Myers and J. M. Jirjees, The Accuracy of Telephone Reference/Information Service in Academic Libraries: Two Studies (Metuchen, N. J.: Scarecrow, 1983); Howard D. White, "Measurement at the Reference Desk," Drexel Library Quarterly 17:3-35 (Winter 1981).

6. Rosemary R. DuMont and Paul F. DuMont, "Measuring Library Effectiveness: A Review and an Assessment," in Advances in Librarianship, ed. M. H. Harris (New York: Academic, 1979).

7. John J. Knightly, "Overcoming the Criterion Problem in the Evaluation of Library Performance," Special Libraries 70:173-78 (Apr. 1979); Mary Casserly, "Academic Library Regional Accreditation," College and Research Libraries 47:39-47 (Jan. 1986).

8. College Library Standards Committee, Association of College and Research Libraries, American Library Association, "Standards for College Libraries, 1985," College and Research Libraries News 46:241-52 (May 1985), p. 242. 
9. Rosemary R. DuMont, "A Conceptual Basis for Library Effectiveness," College and Research Libraries 41:103-11 (Mar. 1980).

\section{APPENDIX A: PROPOSED ACADEMIC LIBRARY STANDARDS FOR USE IN SELF-STUDY PROCESSES AND REGIONAL ACCREDITATION}

The primary standards are those statements that utilize the verb must to indicate that the achievement of these standards, according to a sample of professionals in the field, ought to be considered mandatory for academic library regional accreditation. The statements immediately below them are the secondary standards. They utilize either the verb should to indicate a professional obligation to achieve, or may to indicate that achievement is optional and, therefore, only advisable.

References to specific performance measures, which experts in the field had agreed were applicable and practical to employ, are cited along with those standards to which they apply. The full citation appears in the references.

\section{Goals and Objectives Standards}

A. The library must develop and communicate goals and objectives for its own program that are compatible with those of the institution.

1. The development and review of goals and objectives should be conducted by the library staff working in concert with the administration, faculty and students.

\section{Collection Standards}

\section{A. The library collection must support the instructional program of the institution.}

1. There should be an organized procedure for the selection and evaluation of library materials in the light of institutional goals that includes, to the degree possible, the cooperation and participation of faculty. ${ }^{1}$

2. The size of the library collection should depend on such criteria as the scope and complexity of the curriculum, level and types of degrees offered, and the size and character of the student body. ${ }^{2}$

3. A representative faculty advisory committee should assist in the development and assessment of the library program in meeting the needs of the faculty and students.

4. The library collection should also seek to stimulate the cultural development of students.

5. Where appropriate, the library should have nonprint materials to support the instructional program of the institution.

6. The library collection should include a diversity of materials which exceed the immediate requirements of the curriculum.

7. While the institution should support its own essentially self-contained library, cooperative relationships with other libraries and agencies may also be developed to supplement the library's own resources. ${ }^{3}$

8. A program for the security and preservation of library materials should be an integral part of the library. ${ }^{4}$

B. The library's collection must be capable of supporting research in specified academic fields if the institution's goals call for it.

1. The library collection should support faculty research and professional development.

\section{Access/Use Standards}

A. Print and nonprint collections must be organized in such a way as to make bibliographic access to materials manageable for users. ${ }^{5}$

1. Reference services should be readily available to respond to users' needs for assistance and accurate information. $^{6}$

2. Audiovisual equipment should be made available in sufficient quantity to serve the needs of the faculty and students for course related work, although in many institutions this may not necessarily be provided by the library per se.

3. Faculty should be encouraged to advocate the use of the library through their instructional methodologies and course requirements.

4. Students and faculty should be oriented to the use of the library through some form of bibliographic instruction program.

5. Computer-based access to bibliographic information and resources may be developed to broaden the library's role as an information center. 
6. Depending on the organizational structure of the institution, the library may develop services other than those associated with traditional library functions, i.e., instructional development, the production of instructional materials, learning laboratories, etc.

B. The library must be open sufficient hours per week to accommodate the information and study needs of users, while the facility itself must be convenient and attractive and provide adequate reading, study, viewing, and listening space.

1. Periodic assessment of the library's use should be conducted to determine its adequacy in responding to meeting the demands of its users.?

2. The users should be surveyed periodically to determine the extent to which their needs for services and materials have been identified and met by the library. ${ }^{8}$

C. Provisions must be made for library users in off-campus locations to have adequate access to library resources and equipment.

1. Where cooperative arrangements with other libraries are created, continuity and consistency of service and availability of materials for the academic library's users should be guaranteed.

IV. Staff Standards

A. The library professional staff must hold appropriate graduate degree(s).

1. Opportunities for professional development should be an integral part of the library program.

2. The libraries should be considered as part of the educational team and have the opportunity

to participate in campuswide committees and senates.

3. The size of the professional and support staff should be such that the library program can be carried out successfully.

4. The salaries of the professional and support staff should be commensurate with the training and experience of comparable others in the institution. ${ }^{9}$

\section{Administration Standards}

A. A sufficient and consistent level of financial support must be provided to assure the satisfactory development and maintenance of resources and services.

B. The library administrator(s) must have the appropriate authority and responsibility for the development and management of the library as well as the opportunity to participate in campuswide planning and governance.

\section{APPENDIX A REFERENCES}

1. Paul B. Kantor, "Vitality: An Indirect Measure," Collection Management 2:83-95 (Spring 1978); William E. McGrath, "The Significance of Books Used According to a Classified Profile of Academic Departments," College and Research Libraries 33:212-19 (May 1972); Lancaster, "Evaluating Collections," p.15-43.

2. Clapp and Jordan, "Quantitative Criteria," p.371-80; Trueswell, "User Circulation Satisfaction," p.204-13.

3. Shaw, "A Journal Resource," p.19-29.

4. Marvine Brand, "Security of Academic Library Buildings," Library and Archival Security 3:39-47 (Sept. 1980).

5. Buckland, Book Availability, 1975; Kantor, "Availability Analysis," p.311-19; Kantor, Objective Performance Measures, 1984; Orr and others, "Development of Methodologic Tools," p.235-67; Schofield, Cooper, and Waters, "Evaluation of An Academic," p.207-27; Urquhart and Schofield,

"Measuring Readers' Failure," p.233-41.

6. White, "Measurement," p.3-35.

7. DeProspo, Altman, and Beasley, Performance Measures, 1973; Ettelt, "Book Use," p.2314-15; Fussler and Simon, Patterns in the Use of Books, 1969; Hindle and Buckland, "In-Library Book Usage," p.265-77; Jain, "Sampling," p.150-55; Jestes and Laird, "A Time Study," p.9-16; Kent, Use of Library Materials, 1979; Shaw, "A Practical Journal," p.479-84.

8. Budd and DiCarlo, "Measures of User Evaluation," p.71-84; Butler and Gratch, "Planning a User Study," p.320-30.

9. M. Westerman, "Salary Comparisons between Academic Librarians and Instructional Faculty," College and Research Libraries 43:346-351 (July 1982). 